УДК 618.2+618. 3):616.12-008.331.4

DOI 10.11603/24116-4944.2021.1.12365

๑Л. Б. Маркін, О. І. Попович, А. І. Попович

Лъвівсъкий національний медичний університет ілені Данила Галицького

\title{
ОСОБЛИВОСТІ РЕАЛІЗАЦІї «ФЕНОМЕНУ ГІПОТЕНЗИВНОЇ ДІЇ ГЕСТАЦІЙНОГО ПРОЦЕСУ》 У ВАГІТНИХ З ІДІОПАТИЧНОЮ АРТЕРІАЛЬНОЮ ГІПОТЕНЗІЕЮ
}

Мета дослідження - визначити провідні прояви «феномену гіпотензивної дії вагітності» у жінок 3 ідіопатичною артеріальною гіпотензією (ІАГ).

Матеріали та методи. Проведено оцінку центральної гемодинаміки за допомогою біоімпедансометрії з використанням аналізатора показників кровообігу АПК-01 та доплерометричне дослідження матково-плацентарного кровотоку в маткових артеріях (МА) у 50 вагітних з ІАГ і 32 вагітних із нормальним артеріальним тиском (АТ) у терміні 30-32 тиж. гестації. Контроль серцевої діяльності плода здійснювали за даними кардіотахограми (КТГ). Морфологічне дослідження плацент породілей проводили за стандартною методикою (забарвлення тканини гематоксиліном-еозином) з використанням світлооптичного мікроскопа «ЛОМО» із стандартними збільшеннями: ×10×20×40×100.

Результати дослідження та їх обговорення. Фізіологічне зниження АТ у 48,0 \% вагітних з ІАГ супроводжувалось появою ознак «вазовагальної непритомності». Особливості клініки фрормувалися за участю автономної нервової системи і свідчили про вегетативний дисбаланс у вагітних з ІАГ. Дослідження показників центральної гемодинаміки у вагітних з ІАГ виявило у 22,0 \% випадків достовірне зниження таких об'ємних показників кровообігу, як УО та ХО серця, що стало тригером зниження перфузії органів і тканин і, як наслідок, порушення матково-плацентарного кровотоку. Доплерометричне дослідження показників кровотоку в МА виявило помірне збільшення пульсаційного індексу (ПІ) у 28,0 \% вагітних з ІАГ: показники судинної резистентності МА були вищими в середньому на 19,0%, ніж у групі контролю. Недостатнє постачання плацентарної тканини оксигенованою кров'ю зумовлювало розвиток компенсованого оретального дистресу у 18,0 \% вагітних з ІАГ. Морфологічна картина плацент підтверджувала наявність хронічної плацентарної дисфоункції у породілей 3 ІАГ у вигляді деструкції значної кількості паренхіматозних елементів і реологічних порушень у міжворсинчастому просторі.

Висновки. Надання допомоги вагітним з ІАГ передбачає урахування ефекту «гіпотензивної дії вагітності», організацію еорективного моніторингу перебігу гестаційного процесу.

Ключові слова: вагітність; ідіопатична артеріальна гіпотензія; акушерські ускладнення; морорологія плаценти.

ОСОБЕННОСТИ РЕАЛИЗАЦИИ «ФЕНОМЕНА ГИПОТЕНЗИВНОГО ДЕЙСТВИЯ ГЕСТАЦИОННОГО ПРОЦЕССА» У БЕРЕМЕННЫХ С ИДИОПАТИЧЕСКОЙ АРТЕРИАЛЬНОЙ ГИПОТЕНЗИЕЙ

Цель исследования - определить ведущие проявления «френомена гипотензивного действия беременности» у женщин с идиопатической артериальной гипотензией (ИАГ).

Материалы и методы. Проведена оценка центральной гемодинамики с помощью биоимпедансометрии с использованием анализатора показателей кровообращения АПК-01 и допплерометрическое исследование маточно-плацентарного кровообращения в маточных артериях (МА) у 50 беременных с ИАГ и 32 беременных с нормальным артериальным давлением (АД) в сроке 30-32 нед. гестации. Контроль сердечной деятельности плода осуществляли по данным кардиотокограммы (КТГ). Морфологическое исследование плацент рожениц проводили по стандартной методике (окрашивание тканей гематоксилином-эозином) с использованием светлооптического микроскопа «ЛОМО» со стандартными увеличениями: $\times 10 \times 20 \times 40 \times 100$.

Результаты исследования и их обсуждение. Физиологическое снижение АД в 48,0 \% беременных с ИАГ сопровождалось появлением признаков «вазовагальных обмороков». Особенности клиники сормировались с участием автономной нервной системы и свидетельствовали о вегетативном дисбалансе у беременных с ИАГ. Исследование показателей центральной гемодинамики у беременных с ИАГ определило в 22,0 \% случаев достоверное снижение таких объемных показателей кровообращения, как УО и МО сердца, что стало триггером снижения перфузии органов и тканей и, как следствие, нарушения маточно-плацентарного кровообращения. Допплерометрическое исследование показателей кровообращения в МА определило умеренное увеличение пульсационного индекса (ПИ) у 28,0 \% беременных с ИАГ; показатели сосудистой резистентности МА были выше в среднем на 19,0 \%, чем в группе контроля. Недостаточное снабжение плацентарной ткани оксигенированной кровью способствовало развитию компенсированного фетального дистресса у $18,0 \%$ беременных с ИАГ. Морфологическая картина плацент подтверждала наличие хронической плацентарной диссрункции у рожениц с ИАГ в виде деструкции значительного количества паренхиматозных элементов и реологических нарушений в межворсинчатом пространстве.

Выводы. Оказание помощи беременным с ИАГ предвидит учет эфффекта «гипотензивного действия беременности», организацию эффрективного мониторинга течения гестационного процесса.

Ключевые слова: беременность; идиопатическая артериальная гипотензия; акушерские осложнения; морфология плаценты.

FEATURES OF REALIZATION OF "PHENOMENON OF HYPOTENSIVE ACTION OF GESTATION PROCESS" IN PREGNANT WOMEN WITH IDIOPATHIC ARTERIAL HYPOTENSION

The aim of the study - to identify the leading manifestations of the "phenomenon of hypotensive effect of pregnancy" in women with idiopathic hypotension (IAH).

Materials and Methods. Central hemodynamics were assessed using bioimpedancemetry using the APK-01 circulatory analyzer and Doppler examination of uterine-placental blood flow in the uterine arteries (UA) in 50 pregnant women with IAH and 
32 pregnant women with normal blood pressure (BP) at 30-32 gestation. Monitoring of fetal heart rate was performed according to cardiotachogram (CTG). Morphological examination of the placenta of women in labor was performed according to standard methods (tissue staining with hematoxylin-eosin) using a light optical microscope "LOMO" with standard magnifications: × $10 \times 20 \times 40 \times 100$.

Results and Discussion. Physiological decrease in blood pressure in $48.0 \%$ of pregnant women with IAH was accompanied by the appearance of signs of "vasovagal fainting". The features of the clinic were formed with the participation of the autonomic nervous system and indicated autonomic imbalance in pregnant women with IAH. The study of central hemodynamic parameters in pregnant women with IAH revealed in $22.0 \%$ of cases a significant decrease in circulatory volume, such as SV and MV of the heart, which was a trigger for reduced perfusion of organs and tissues and, consequently, impaired uteroplacental blood flow. Doppler study of blood flow in UA revealed a moderate increase in pulsation index (PI) in $28.0 \%$ of pregnant women with IAH; indicators of vascular resistance of UA were higher, on average, by $19.0 \%$ than in the control group. Insufficient supply of placental tissue with oxygenated blood led to the development of compensated fetal distress in $18.0 \%$ of pregnant women with IAH. The morphological picture of the placenta confirmed the presence of chronic placental dysfunction in women with IAH in the form of destruction of a significant number of parenchymal elements and rheological disorders in the intervillous space.

Conclusions. Providing assistance to pregnant women with IAH involves taking into account the effect of "phenomenon of hypotensive action of pregnancy", the organization of effective monitoring of the gestational process.

Key words: pregnancy; idiopathic hypotension; complications of pregnancy; placental morphology.

ВСтУП. Передусім слід ураховувати, що за нормального перебігу вагітності артеріальний тиск (АТ) має тенденцію до зниження. Зниження АТ починає відбуватися з діастолічного компонента в першому триместрі і продовжується у другому триместрі зниженням як систолічного (САТ), так і діастолічного (ДАТ) тиску. Зазначене явище отримало назву «френомен гіпотензивної дії вагітності» [1-5]. Урахування цього фрізіологічного процесу важливе для ведення вагітних 3 ідіопатичною артеріальною гіпотензією (ІАГ) (МКX-10-I 95.0), оскільки в деяких випадках з'являються ознаки дезадаптації материнського організму до повсякденної активності, спостерігаються ортостатичні явища, які в зарубіжній літературі мають назву «вазовагальна непритомність» (vasovagal syncope) [6-9]. Етіологічних доказів щодо ІАГ залишається мало. Вважають, що патофрізіологічною особливістю ІАГ $€$ зниження скоротливої фрункції серця та швидкісних параметрів внутрішньосерцевої гемодинаміки $[10,11]$. Порушення центральної гемодинаміки слугує тригером для виникнення судинних розладів та порушень мікроциркуляції у жінок 3 ІАГ, супроводжується системними гемодинамічними зрушеннями, зниженням перфузії органів і тканин і, як наслідок, ускладненнями з боку матері й плода [12-19].

Зазначене зумовлює актуальність подальшого поглибленого дослідження особливостей перебігу вагітності у жінок з ІАГ.

МЕТА ДОСЛІДЖЕННЯ - вИзНачитИ провідні прояви «феномену гіпотензивної дії вагітності» у жінок з ІАГ.

МАТЕРІАЛИ ТА МЕТОДИ. Основну групУ спостереження склали 50 вагітних з ІАГ, контрольну - 32 вагітних із нормальним артеріальним тиском (АТ) у терміні 30 32 тиж. гестації.

Усі вагітні були проінформовані про мету дослідження і дали згоду на участь у його проведенні. Критерієм включення в обстеження був підтверджений діагноз ІАГ шляхом добового моніторування артеріального тиску: рівень систолічного артеріального тиску (САТ) <100 мм рт. ст., діастолічного артеріального тиску (ДАТ) <60 мм рт. ст., відсутність уроджених захворювань серця і судин, дисплазії сполучної тканини у вигляді синдрому Марфана, Елерса-Данлоса, колагенозів, гіпотиреозу, надниркової недостатності, інсекційних захворювань, ревматичної хвороби.

Стан центральної гемодинаміки у жінок оцінювали за допомогою біоімпедансометрії з використанням аналізатора показників кровообігу АПК-01. Визначали частоту серцевих скорочень (ЧСС), ударний об'єм (УО) і хвилинний об'єм (XO) серця, загальний периферійний судинний опір (ЗПСО). Особливу увагу було присвячено реєстрації проявів синдрому «вазовагальної непритомності».

Дослідження матково-плацентарного кровотоку проводили на ультразвуковому діагностичному приладі «SA-8000 EX» (Medison, Південна Корея). При цьому використовували кольорове доплерівське картування й імпульсну доплерометрію маткових артерій (МА). Оцінку кривих швидкостей кровотоку здійснювали шляхом визначення пульсаційного індексу (ПІ) в обох артеріях з урахуванням середнього значення. ПІ виражається відношенням різниці між максимальною систолічною та кінцевою діастолічною швидкостями до середньої швидкості кровообігу (ПІ=А-Д/М), де А - максимальна систолічна швидкість кровообігу, Д-кінцева діастолічна швидкість кровообігу, М - середня швидкість кровообігу. При аналізі результатів доплерограсрії врахували рекомендації Л. Б. Маркіна та співавт. (1993) [20].

Кардіомонітором 8030А фрірми «Hewlett-Packard» (США) здійснювали контроль серцевої діяльності плода. Вагітним надавали напівфовлерівського положення. Запис кардіотахограми (КТГ) проводили впродовж 20 хв на стрічці, що рухалась із швидкістю $1 \mathrm{~cm} /$ хв. При аналізі КТГ враховували такі показники: базальну частоту серцевих скорочень (БЧСС), амплітуду миттєвих осциляцій (АМО), частоту миттєвих осциляцій (ЧМО), амплітуду повільних осциляцій (АПО), частоту повільних осциляцій (ЧПО), частоту виявлення та тривалість ділянок монотонності ритму (ділянки з АМО й АПО, що не перевищують 3 уд/хв), кількість, амплітуду, тривалість і характер акцелерацій і децелерацій чСС плода. Оцінку КТГ проводили за шкалою W. Fisher et al. (1976).

Морфологічне дослідження плацент породілей проводили за стандартною методикою (забарвлення тканини гематоксиліном-еозином) з використанням світлооптичного мікроскопа «ЛОМО» із стандартними збільшеннями: $\times 10 \times 20 \times 40 \times 100$.

Для перевірки нормальності розподілу кількісних даних застосовано критерій Шапіро-Уїлка. У випадку гаусівського розподілу варіаційні ряди описувались за допомогою середнього арифметичного та його стандарт-

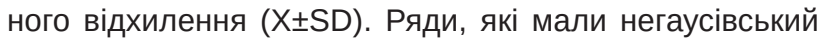
розподіл, описували за допомогою медіани та 25-го і 75-го перцентилів: Мe [25 \%; 75 \%]. 
Значущість різниці між двома середніми величинами визначали при нормальному розподілі за допомогою t-критерію Стьюдента, а при відсутності гаусівського розподілу - U-критерію Манна-Уїтні. Різницю вважали достовірною при p<0,05. Кореляційні залежності вимірювали за допомогою коефіцієнта кореляції Пірсона (при кількісних показниках) або коефріцієнта кореляції Спірмена (при рангових показниках).

Всі статистичні обчислення проводили із використанням програмного забезпечення RStudio v. 1.1.442 та R Commander v.2.4-4.

РЕЗУЛЬТАТИ ДОСЛІДЖЕННЯ ТА ЇХ ОБГОВОРЕННЯ. Фізіологічне зниження АТ у 48,0 \% вагітних з ІАГ супроводжувалось появою ознак «вазовагальної непритомності». Спостерігали напади головного болю, нудоти, слабості й підвищеної втомлюваності зранку, емоційної лабільності. У 72,0 \% випадків жінки скаржились на задишку, головокружіння, мерзлякуватість кистей і стоп, прояви з боку серцево-судинної системи - лабільність пульсу, біль у ділянці серця, брадикардію. У 12,0 \% мали місце гіпотонічні кризи. Особливості клініки фрормувалися за участю автономної нервової системи і свідчили про вегетативний дисбаланс у вагітних з ІАГ.

Дослідження показників центральної гемодинаміки у вагітних з ІАГ виявило у 22,0 \% випадків достовірне зниження таких об'ємних показників кровообігу, як УО та ХО серця (відповідно, $(57,8 \pm 2,6)$ мл та $(4,3 \pm 0,2)$ л/хв), порівняно 3 аналогічними показниками у жінок з неускладненим перебігом вагітності (УО становив $(65,3 \pm 3,2)$ мл, а ХО серця $(5,5 \pm 0,3)$ л/хв) $(p<0,05)$. Водночас середні показники 3ПСО перебували в межах норми $((1208,0 \pm 47,2)$ дин·с. см 5$)$.

При неускладненому перебігу вагітності кровотік у МА мав двофразний спектр і характеризувався низькою пульсацією та високим діастолічним компонентом.

Доплерометричне дослідження показників кровотоку в МА виявило помірне збільшення ПІ у 28,0 \% вагітних з ІАГ. Так, показники судинної резистентності МА у вагітних з ІАГ були вищими в середньому на 19,0 \%, ніж у групі контролю (у правій МА 0,97 [0,7-1,17]; 0,73 [0,55-0,89]; у лівій МА $1,17[0,95-2,0] ; 0,76[0,38-0,96] ;$ середнє значення 1,09 [0,97-1,13]; 0,74 [0,46-0,85] відповідно) ( $p<0,05)$. Детальний аналіз доплерограм МА у вагітних з ІАГ показав, що криві швидкостей кровотоку характеризувалися низьким діастолічним компонентом. ІСО були достовірно нижчими на боці прикріплення плаценти, що свідчило про вищу інтенсивність маткового кровотоку, зумовлену більшою периферійною судинною сіткою МА на боці плацентації.

Інтенсивність матково-плацентарного кровотоку $€$ основним чинником, який визначає надходження кисню до плода. Недостатнє постачання плацентарної тканини оксигенованою кров'ю зумовлює розвиток компенсованого фетального дистресу у 18,0 \% вагітних з ІАГ. При цьому КТГ дослідження виявляло наявність помірної тахікардії (БЧСС - $(165,2 \pm 4,7)$ уд/хв). Частота виявлення монотонності ритму сягала 52,0 \%. Мало місце достовірне зниження амплітуди і частоти як миттєвих (АМО - $(2,66 \pm$ $0,27)$ уд/хв; ЧМО - $(3,05 \pm 0,24)$ осцил/хв), так і повільних (АПО - $(6,52 \pm 0,32)$ уд/хВ; ЧПО - $(5,07 \pm 0,31)$ осцил/Хв) осциляцій $(p<0,05)$. Тривалість ділянок монотонності ритму чСС плода складала, в середньому, $(44,52 \pm 2,54) \%$ запису. Транзиторні прискорення ЧСС плода амплітудою $(16,48 \pm 1,16)$ уд/хв, тривалістю $(16,72 \pm 1,32)$ с були зареєстровані у 56,0 \% випадків. Середня кількість акцеле- рацій за 20-хвилинний період спостереження складала

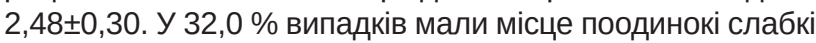
пікоподібні децелерації.

Специфрічні прояви «феномену гіпотензивної дії вагітності» були виявлені при морфологічному дослідженні плацент породілей з ІАГ. Так, у 64,0 \% випадків у базальній пластинці виявлено різної величини ділянки звапнення, крововиливи, у 16,0 \% - ділянки склерозу. У базальному інтервільозному просторі в усіх випадках відмічали вогнищеві крововиливи, надмірне відкладання фрібриноїду з утворенням псевдоінорарктів. У 36,0 \% випадків спостерігали нерівномірне зменшення інтервільозного простору з розвитком афрункціональних зон, у 32,0 \% - гострий тромбоз (рис. 1).

Крім зазначеного, в усіх випадках у стромі проміжних та термінальних ворсин були наявні набряк, периваскулярний склероз, проліферація ендотелію (рис. 2).

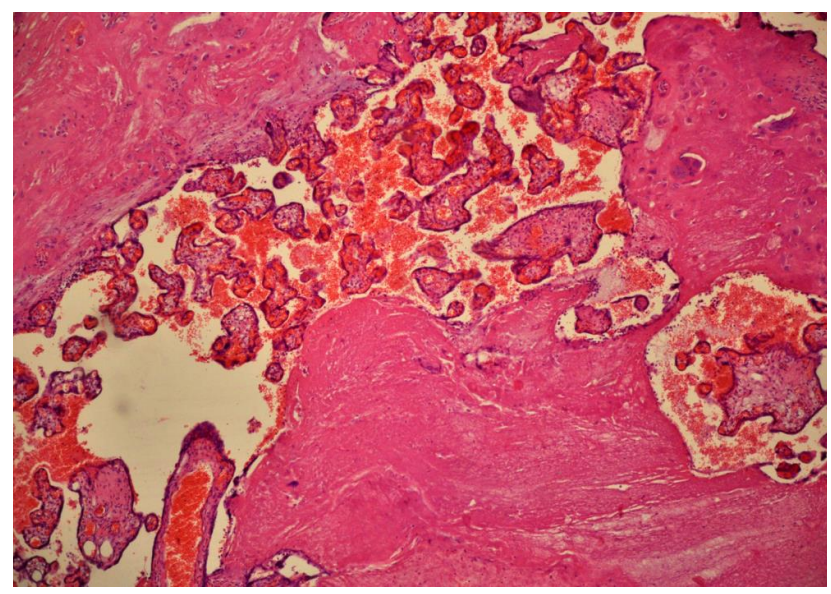

Рис. 1. Гістологічний препарат материнської частини плаценти. У базальній пластині надмірне відкладання фрібриноїду та вогнищевий склероз. У базальному інтервільозному просторі крововиливи, гострий тромбоз, ішемічні інсраркти. Фарбування гематоксиліном та еозином. Зільшення 100.

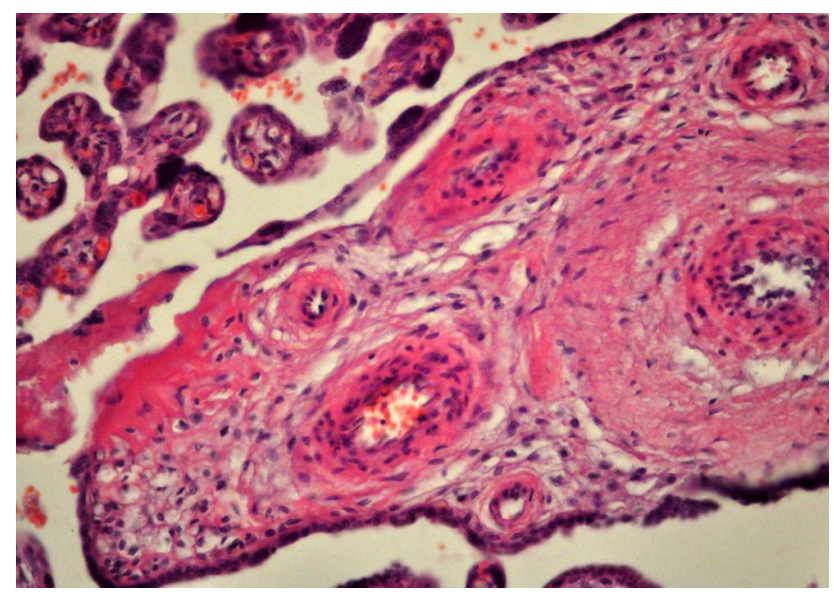

Рис. 2. Гістологічний препарат плодової частини плаценти. Гіперплазія ендотеліоцитів стінок артеріол, артерій та вен опірних ворсин, в деяких з облітерацією просвіту. Вогнищеве відкладання фрібриноїду в ділянках пошкодження синцитіотрофобласта. Периваскулярний склероз. Множинні синцитіальні бруньки у термінальних ворсинах. Фарбування гематоксиліном та еозином. Зільшення 400. 
У 16,0 \% випадків, крім цих змін, виявляли орібриноїдний некроз та крововиливи в стромі. Дуже рідко зустрічали проліферацію ендотелію у стовбурових ворсинах.

У всіх плацентах породілей з ІАГ відзначено високий рівень компенсаторних процесів, що проявились вираженим розвитком синцитіальних вузликів та ангіоматозом строми проміжних і термінальних ворсин (рис. 3).

Наявність виражених змін у інтервільозному просторі у жінок з ІАГ призводила до порушення міжворсинкового кровообігу. Склероз строми термінальних ворсин зумов-

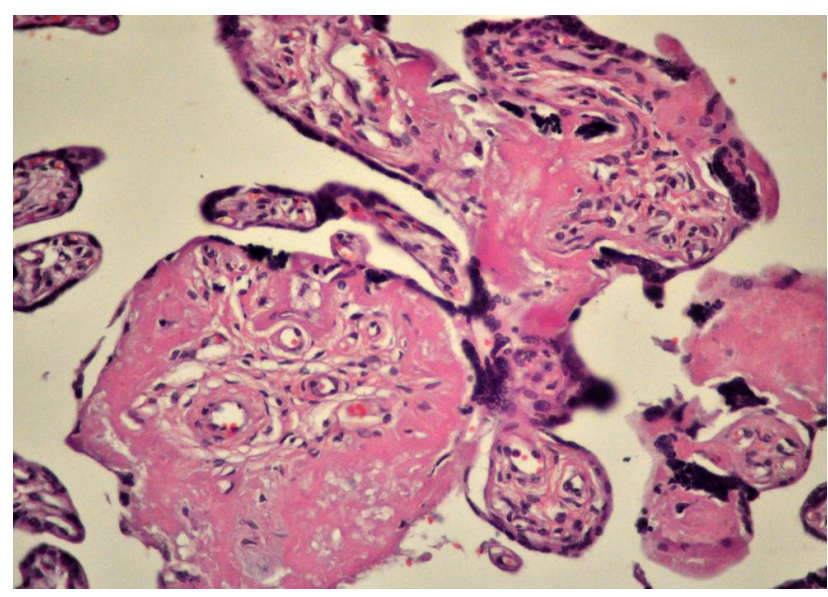

Рис. 3. Гістологічний препарат плодової частини плаценти. Відкладання фрібриноїду на поверхні проміжних та термінальних ворсин у ділянках пошкодження синцитіотрофоббласта з утворенням множинних синцитіальних бруньок. Склероз строми ворсин. Фарбування гематоксиліном та еозином. Зільшення 400.

ВИСНОВкИ. 1. У жінок з ІАГ у 48,0 \% випадків спостерігаються прояви «феномену гіпотензивної дії вагітності».

2. Гіпотензивна дія вагітності зумовлює прояви «вазовагальної непритомності» у жінок з ІАГ, впливає на матково-плацентарний кровотік, морфоорункціональний стан плаценти, зумовлюючи розвиток компенсованого фретального дистресу.

\section{СПИСОК ЛІТЕРАТУРИ}

1. Медведь В. І. Артеріальна гіпертензія у вагітних: що змінилося і що залишилося незмінним? / В. І. Медведь // Здоров'я України. - 2013. - № 2 (27). - С. 69.

2. Adding droxidopa to fludrocortisone or midodrine in a patient with neurogenic orthostatic hypotension and Parkinson disease / D. Kremens, M. Lew, D. Claassen, B. Goodman // Clin. Auton. Res. - 2017. - Vol. 27 (Suppl 1). - P. 29-31.

3. Orthostatic hypotension: a review. / A. Joseph, R. Wanono, M. Flamant, E. Vidal-Petiot // Nephrol. Ther. - 2017. - Vol. 13 (Suppl. 1). - P. 55-67.

4. Arnold A. C. Orthostatic hypotension: a practical approach to investigation and management / A. C. Arnold, S. R. Raj // Can. J. Cardiol. - 2017. - Vol. 33 (12). - P. 1725-1728.

5. Orthostatic hypotension: JACC State-of-the-Art review / R. Freeman, A. R. Abuzinadah, C. Gibbons [et al.] // J. Am. Coll. Cardiol. - 2018. - Vol. 72 (11). - P. 1294-1309.

6. Choi W. Vagolytic atropine attenuates cerebral vasodilation response during acute orthostatic hypotension / W. Choi, K. Lee, Y. Kim // Korean J. Anesthesiol. - 2015. - Vol. 68 (6). - P. 594-602. лював порушення синусоїдальної транссрормації капілярів, а це, в свою чергу, зумовлювало зменшення числа синцитіокапілярних мембран, що сприяло виникненню хронічної дисфрункції плаценти (рис. 4).

Таким чином, морфологічна картина плацент породілей з ІАГ виявляла деструкцію значної кількості паренхіматозних елементів і порушення мікроциркуляції, що призводило до декомпенсованої недостатності плаценти, наслідком якої стало фрормування фретального дистресу у $18,0 \%$ випадків.

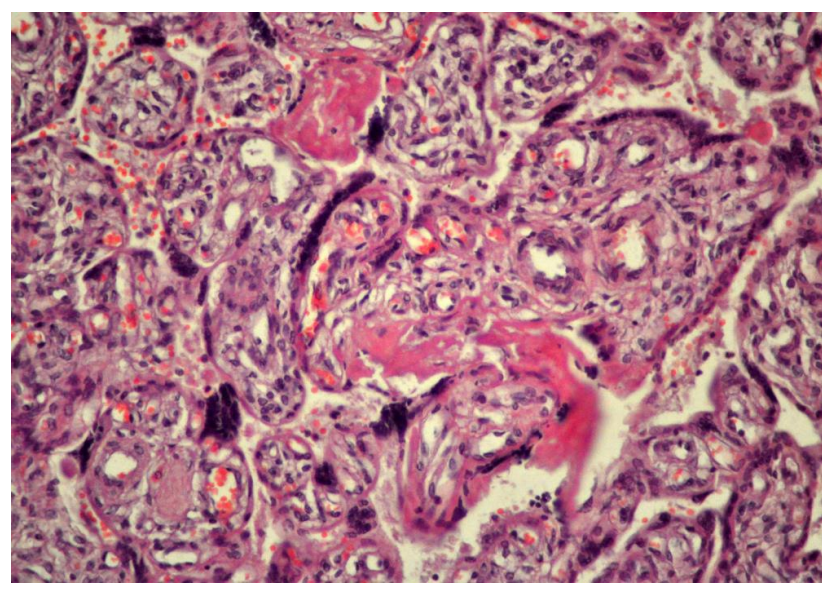

Рис. 4. Гістологічний препарат плодової частини плаценти. Ділянка афрункціональної зони з утворенням множинних синцитіальних бруньок у проміжних та термінальних ворсинах та незначним відкладанням фрібриноїду в інтервільозному просторі. Фарбування гематоксиліном та еозином. Зільшення 400.

3. Надання допомоги вагітним з ІАГ передбачає врахування есректу «гіпотензивної дії вагітності», організацію ефрективного моніторингу перебігу гестаційного процесу.

ПЕРСПЕКТИВИ ПОДАЛЬШИХ ДОСЛІДЖЕНЬ. Наведені результати дослідження прояву «феномену гіпотензивної дії вагітності» у жінок з ІАГ вказують на доцільність удосконалення моніторингу гестаційного процесу у вказаного контингенту вагітних.

7. Fedorowski A. Syndromes of orthostatic intolerance: a hiddendanger / A. Fedorowski, O. Melander // J. Intern. Med. 2013. - Vol. 273 (4). - P. 322-335.

8. Воробей Л. І. Порушення нейровегетативної регуляції і вагітність: вплив на розвиток гестаційних ускладнень / Л. І. Воробей // Здоровье женщины. -2015. - № 6 (102). - С. 97-98.

9. Подольський Вл. В. Особливості стану вегетативного гомеостазу у жінок фрертильного віку зі змінами репродуктивного здоров'я / Вл. В. Подольський // Здоровье женщины. - 2015. - № 5 (101). - С. 145-149.

10. Баев В. М. Патогенетическая роль автономной нервной системы в ремоделировании сердца при артериальной гипотензии / В. М. Баев, Т. Ю. Агафонова // Кардиоваскулярная терапия и профилактика. - 2019. № 18 (1). - C. 67-72.

11. Pickard J. M. Intrinsic cardiac ganglia and acetylcholine are important in the mechanism of ischaemic preconditioning / J. M Pickard, N. Burke, S. M. Davidson // Basic Res. Cardiol. 2017. - No. 112 (2). - P. 11. 
12. Пестрикова Т. Ю. Характеристика основных показателей функционирования фетоплацентарного комплекса у беременных женщин с артериальной гипотензией / Т. Ю. Пестрикова, О. Л. Ильиных, Е. А. Юрасова // Дальневосточный медицинский журнал. - 2012. - № 3. - С. 36-40.

13. Баев В. М. Прогностическая значимость артериальной гипотензии при беременности и родах / В. М. Баев // Практическая медицина. - 2018. - Т. 16, № 6. - С. 20-25.

14. Критическое состояние плода: диагностические критерии, акушерская тактика, перинатальные исходы / А. Н. Стрижаков, И. В. Игнатко, Е. В. Тимохина, М. А. Карданова. - М. : ГЭОТАР-Медиа, 2018. - 176 с.

15. Маркін Л. Б. Доплерометричне дослідження матково-плацентарно-плодового кровоплину у вагітних з первинною артеріальною гіпотонією / Л. Б. Маркін, О.І.Попович,

\section{REFERENCES}

1. Medved, V.I. (2013). Arterialna hipertenziia u vahitnykh: shcho zminylosia i shcho zalyshylosia nezminnym? [Hypertension in pregnant women: what has changed and what has remained unchanged?] Zdorovia Ukrainy - Health of Ukraine, 2 (27), 69 [in Ukrainian].

2. Kremens, D., Lew, M., Claassen, D., \& Goodman, B. (2017). Adding droxidopa to fludrocortisone or midodrine in a patient with neurogenic orthostatic hypotension and Parkinson disease. Clin. Auton. Res., 27 (Suppl. 1), 20-31. DOI: 10.1007/s10286-017-0434-6.

3. Joseph, A., Wanono, R., Flamant, M., \& Vidal-Petiot, E. (2017). Orthostatic hypotension: a review. Nephrol. Ther., 13 (Suppl. 1), 55-67. DOI: 10.1016/j.nephro.2017.01.003.

4. Arnold, A.C., \& Raj, S.R. (2017). Orthostatic hypotension: a practical approach to investigation and management. Can. J. Cardiol., 33 (12), 1725-1728. DOI:10.1016/j.cjca.

5. Freeman, R., Abuzinadah, A.R., Gibbons, C., Jones, P., Miglis, M.G., \& Sinn, D.I. (2018). Orthostatic hypotension: JACC State-of-the-Art Review. J. Am. Coll. Cardiol., 72 (11), 12941309. DOI: 10.1016/j.jacc.2018.05.079.

6. Choi, W., Lee, K., \& Kim, Y. (2015). Vagolytic atropine attenuates cerebral vasodilation response during acute orthostatic hypotension. Korean. J. Anesthesiol., 68 (6), 594-602. DOI: 10.4097/kjae.2015.68.6.594.

7. Fedorowski, A., \& Melander, O. (2013). Syndromes of orthostatic intolerance: a hiddendanger. J. Intern. Med., 273 (4) 322-335. DOI: 10.1111/joim.12021.

8. Vorobei, L.I. (2015). Porushennia neirovehetatyvnoi rehulatsii i vahitnist: vplyv na rozvytok hestatsiinykh uskladnen [Irregularities of neurovegetative regulation and pregnancy: impact on the development of gestational complications]. Zdorovye zhenshchiny - Woman's Health, 6 (102), 97-98 [in Ukrainian].

9. Podolskyi, VI.V. (2015). Osoblyvosti stanu vehetatyvnoho homeostazu u zhinok fertylnoho viku z zminamy reproduktyvnogo zdorovia [Features of the state of vegetative homeostasis in women of fertile age with changes in reproductive health]. Zdorovye zhenshchiny - Woman's Health, 5, 145-149 [in Ukrainan].

10. Bayev, V.M., \&Agafonova, T.Yu. (2019). Patogeneticheskaya rol avtonomnoy nervnoy sistemy $v$ remodelirovanii serdtsa pri arterialnoy gipotenzii [The pathogenetic role of the autonomic nervous system in heart remodeling in arterial hypotension]. Kardiovaskulyarnaya terapiya i profilaktika - Cardiovascular Therapy and Prevention, 18 (1), 67-72. DOI: 10.15829/17288800-2019-1-67-72 [in Russian].

11. Pickard, J.M., Burke, N., \& Davidson, S.M. (2017). Intrinsic cardiac ganglia and acetylcholine are important in the
А. І. Попович // Актуальні питання педіатрії, акушерства і гінекології. - 2017. - № 1. - С. 100-104.

16. Duschek S. Autonomic cardiovascular control and executive function in chronic hypotension/S. Duschek, A. Hoffmann, G. A. Reyes Del Paso // Ann. Behav. Med. - 2017. - No. 3 (51). - P. 442-445.

17. Hohmann M. Low blood pressure in pregnancy / M. Hohmann, W. Kunzel // Z. Geburtshilfe Neonatol. - 2007. Vol. 211 (2). - P. 45-53.

18. Апресова К. Г. Особенности маточно-плацентарного кровообращения при артериальной гипотонии у беременных / К. Г. Апресова, Е. Н. Дзюба // Перинатология и педиатрия. - 2006. - № 3 (27). - C. 81-82.

19. Fleming L. NO: the primary EDRF / L. Fleming, R. Busse // J. Mol. Cell. Cardiol. - 1999. - № 31. - P. 5-14.

20. Маркін Л. Б. Біофрізичний моніторинг плода / Л. Б. Маркін, Б. М. Венцківський, К. В. Воронін. - Львів : Світ, 1993. - 68 с.

mechanism of ischaemic preconditioning. Basic. Res. Cardiol., 112 (2), 11. DOI: 10.1007/s00395-017-0601-x.

12. Pestrikova, T.Yu., Ilinykh, O.L., \& Yurasova, Ye.A. (2012). Kharakteristika osnovnykh pokazateley funktsionirovaniya fetoplatsentarnogo kompleksa u beremennykh zhenshchin s arterialnoy gipotenziyey [Characteristics of the main indicators of the functioning of the fetoplacental complex in pregnant women with arterial hypotension]. Dalnevostochnyy meditsinskiy zhurnal - Far Eastern Medical Journal, 3, 36-40 [in Russian].

13. Bayev, V.M. (2018). Prognosticheskaya znachimost arterialnoy gipotenzii pri beremennosti i rodakh [Prognostic significance of arterial hypotension during pregnancy and childbirth]. Prakticheskaya meditsina - Practical Medicine, 16 (6), 20-25 [in Russian].

14. Strizhakov, A.N., Ihnatko, I.V., Timokhina, E.V. \& Kardanova, M.A. (2018). Kriticheskoye sostoyaniye ploda:diagnosticheskiye kriterii, akusherskaya taktika, perinatalnyye iskhody [Fetal condition: diagnostic criteria, obstetric tactics, perinatal outcomes]. Moscow [in Russian].

15. Markin, L.B., Popovych, O.I. \& Popovych, A.I. (2017). Doplerometrychne doslidzhennia matkovo-platsentarno-plodovoho krovoplynu u vahitnykh z pervynnoiu arterialnoiu hipotoniieiu [Doppler examination of uterine-placental-fetal hemodynamic in pregnant women with arterial hypotension]. Aktualni pytannia pediatrii, akusherstva ta hinekolohii - Actual Problems of Pediatrics, Obstetrics and Gynecology, 1, 100-104. DOI: 10.11603/24116-4944.2017.1.7397 [in Ukrainian].

16. Duschek, S., Hoffmann, A., \& Reyes Del Paso, G.A. (2017). Autonomic cardiovascular control and executive function in chronic hypotension. Ann. Behav. Med., 3 (51), 442-445. DOI: 10.1007/s12160-016-9868-7.

17. Hohmann, M., \& Kunzel, W. (2007). Low blood pressure in pregnancy. Z. Geburtshilfe Neonatol., 2, 45-53. DOI: 10.1055/s-2006-933493.

18. Apresova, K.G., \& Dzyuba, E.N. (2006). Osobennosti matochno-platsentarnogo krovoobrashcheniya pri arterialnoi hipotonii u beremennykh [Features utero-placental blood flow during hypotension in pregnant]. Perinatologiya i pediatriya Perinatology and Pediatrics, 3 (27), 81-82 [in Ukrainian].

19. Fleming, L. \& Busse. R. (1999). NO: the primary EDRF. J. Mol. Cell. Cardiol, 31, 5-14. DOI: 10.1006/jmcc.1998.0839.

20. Markin, L.B., Ventskivskyi, B.M., \& Voronin, K.V. (1993). Biofizychnyy monitorynh ploda [Biophysical monitoring of the fetus]. Lviv: Svit [in Ukrainian].

Отримано 16.03.2021

Прийнято до друку 09.04.21

Електронна адреса для листування: popallochka@ukr.net 